\title{
PENINGKATAN HASIL BELAJAR DAN DISPOSISI MATEMATIS SISWA DALAM MENYELESAIKAN SOAL CERITA BARISAN DAN DERET MELALUI MODEL PEMBELAJARAN LAPS HEURISTIK BERBANTUAN APLIKASI WHATSAPP
}

\author{
Rika Nur Safitri $^{\mathrm{a}}$, Ali Shodikin ${ }^{\mathrm{b}}$, Arezqi Tunggal Asmana ${ }^{\mathrm{c}}$ \\ ${ }^{a}$ Program Studi Pendidikan Matematika Universitas Islam Darul 'Ulum Lamongan, \\ rikanursafitri07@gmail.com, Jl. Airlangga No. 03 Sukodadi, Lamongan. \\ ${ }^{b}$ Program Studi Pendidikan Matematika Universitas Islam Darul 'Ulum Lamongan, \\ alishodikin@unisda.ac.id, Jl. Airlangga No.03 Sukodadi, Lamongan. \\ 'Program Studi Pendidikan Matematika Universitas Islam Darul 'Ulum Lamongan, \\ arezqitunggal@unisda.ac.id, Jl. Airlangga No.03 Sukodadi, Lamongan.
}

\begin{abstract}
ABSTRAK
Penelitian ini berujuan untuk mengetahui peningkatan hasil belajar dan disposisi matematis siswa dalam menyelesaikan soal cerita barisan dan deret melalui model pembelajaran LAPS Heuristik berbantuan WhatsApp Messenger. Jenis penelitian ini adalah eksperimen dengan pendekatan kuantitatif. Metode pengumpulan data dilakukan dengan metode tes dan angket. Penelitian dilakukan dengan memberikan 4 butir soal pretes dan postes mengenai penyelesain masalah barisan dan deret serta angket disposisi amtematis pada awal dan akhir penelitian. Teknik analisis data yang digunakan adalah Uji normalitas, Uji homogenitas dan uji perbedaan rata-rata. Hasil dari penelitian menunjukkan: (1) ada perbedaan pencapaian hasil belajar dan disposisi matematis peserta didik dalam menyelesaikan soal cerita barisan dan deret melalui pembelajaran LAPS Heuristik berbantuan WhatsApp dengan pembelajaran kovensional; (2) ada perbedaan peningkatan hasil belajar dan disposisi matematis peserta didik dalam menyelesaikan soal cerita barisan dan deret melalui model pembelajaran LAPS Heuristik berbantuan aplikasi WhatsApp.
\end{abstract}

Kata Kunci: Hasil Belajar, disposisi matematis, barisan dan deret, LAPS Heuristik.

\section{ABSTRACT}

This study aims to determine the increase in learning outcomes of student's mathematical disposition in solving story sequence and sequence problem through the learning model LAPS Heuristic assisted by Whatsapp messenger. this type of research is an esperiment with a quantitative approach. Data collection method is done by the method of test and questionnaire. The study was conducted by giving 4 items of pretest and posttest regarding the settlement of row and series problems and a mathematical disposition questionnaire at the beginning and end of the study. The data analysis echnique used is the normaity test, the homogeneity test and the average difference test. Theresult of the study indicate: (1) there are differences in the achievement of learning outcomes and student's mathematical disposition in solving story sequence questions and sequencesthrough learning LAPS Heuristic of Whatsapp assisted with conventional learning; (2) there is a difference in the improvement of learning outcomes and the mathematical disposition of students in solving story sequence questions and sequence through the learning model assisted by the whatsapp application.

Keywords: Learning outcomes, mathematical disposition, sequence and series, LAPS Heuristic learning model 


\section{PENDAHULUAN}

Selain kemampuan kognitif, siswa juga harus memiliki kemampuan afektif. Seperti yang tercantum dalam tujuan pembelajaran matematika di sekolah, yaitu memiliki sikap menghargai kegunaan matematika dalam kehidupan, sikap rasa ingin tahu, perhatian dan minat dalam belajar matematika, serta sikap ulet dan percaya diri dalam menyelesaikan (BSNP, 2006:140). Hal ini dikarenakan pembelajaran matematika tidak hanya berhubungan dengan pembelajaran konsep, prosedural dan aplikasinya, namun juga berhubungan dengan minat dan ketertarikan terhadap matematika sebagai cara yang powerfull sebagai cara menyelesaikan masalah (Dahlan, 2011:847). Minat dan ketertarikan terhadap matematika akan membentuk kecenderungan yang kuat yang disebut disposisi matematis.

Disposisi matematis peserta didik yang rendah bisa muncul karena peserta didik tidak bisa menyelesaikan masalah atau soal matematika yang diberikan. Dalam menyelesaikan masalah, siswa sering kurang bersemangat dan percaya diri dalam belajar matematika. Seperti yang diungkapkan Syaban (Gustami, 2017:03) bahwa pada saat ini disposisi matematis peserta didik masih belum tercapai. Seseorang yang mempunyai disposisi matematis yang tinggi akan membuat individu yang tangguh, ulet, tanggung jawab, memiliki prestasi yang tinggi serta membantu indvidu mencapai hasil terbaiknya (Sumarno, 2012:02). Hal ini dikarenakan ada hubungan yang positif antara sikap terhadap matematika dan prestasi yang diperolehnya (Mullis, Martin, Foy, Arora, 2012:326). Selain itu, disposisi matematis juga mempunyai hubungan interaksi antara kemampuan awal matematis siswa dan strategi pembelajaran yang diterapkan (Shodikin, 2015).

Kesulitan yang dialami banyak peserta didik dalam matematika diantaranya dalam hal penyelesaian masalah yang berhubungan dengan soal cerita. Kesulitan yang sering dialami peserta didik adalah diantaranya tidak mampu memahami dan mengubah soal ke dalam bahasa matematika yang berujung peserta didik mengalami kesalahan dalam menulis angka (Putri, 2008). Kementrian Pendidikan dan Kebudayaan (2013) juga menjelaskan mengenai analisis hasil PISA tahun 2009 yaitu hampir semua peserta didik di Indonesia hanya menguasai pelajaran sampai level 3 saja, sementara negara lain banyak yang sampai level 4,5 bahkan 6 . Begitu juga dengan hasil PISA tahun 2012 dan tahun 2015, siswa Indonesia 
masih mengalami hal yang serupa. Hanya sedikit peserta didik yang mampu mengerjakan soal PISA level 4, 5 dan 6.

Rendahnya kemampuan penyelesaian masalah bisa disebabkan karakter matematika yang abstrak dan sulit menurut peserta didik (Fitria dkk, 2018). Ada peserta didik yang menyenangi matematika tapi hanya di permukaannya saja, peserta didik berkenalan dengan konsep matematika yang sederhana dan merasa bangga ketika bisa menyelesaikan soal dari yang dipahami, tetapi, semakin tinggi sekolah dan semakin sukar konsep yang dipelajari oleh peserta didik maka semakin berkurang juga minatnya terhadap matematika. Disamping itu, masih ada banyak siswa yang mengalami kesulitan meskipun dengan konsep matematika yang sederhana. Seorang guru dituntut untuk untuk mampu menanamkan konsep matematika dengan benar agar peserta didik mampu merekamnya dengan baik. Untuk membantu peserta didik dalam menyelesaikan masalah perlu dilakukan identifikasi kesalahan dalam menyelesaikan soal tersebut. Ini bertujuan agar guru dapat membimbing dengan benar dimana kesalahan peserta didik tadi sehingga kemampuannya bertambah dengan baik.
Materi barisan dan deret merupakan materi yang membutuhkan penyelesaian yang beragam sehingga diperlukan kemampuan penyelesaian masalah yang tepat. Namun, sering dijumpai dalam kelas peserta didik masih kesulitan dalam memilih model penyelesaian masalah dengan materi yang sesuai.

Berdasarkan penjelasan disposisi matematis dan penyelesaian masalah yang sudah ada di atas, diperlukan solusi untuk mengatasi masalah yang dihadapi saat ini. Salah satu faktor yang menyebabkan kondisi tersebut adalah penerapan model pembelajaran yang kurang tepat dalam proses pembelajaran. Dalam hal ini adalah model pembelajaran yang inovatif dan mampu memfasilitasi siswa belajar dengan menyenangkan. Salah satu model pembelajaran yang bisa memberikan hal tersebuat adalah model pembelajaran LAPS Heuristic. Model pembelajaran ini berlandasan paradigma konstruktivistik. Pada model ini pembelajaran berpusat pada peserta didik, dimana peserta didik diberikan kesempatan untuk mengkonstruksi pengetahuannya sendiri (Adiarta, 2016) yaitu bermula dari mengetahui tentang apa masalahnya, adakah alternatifnya, apakah bermanfaat, apakah solusinya dan bagaimana sebaiknya mengerjakannya. Selain itu model pembelajaran LAPS 
Heuristic juga mengajak peserta didik untuk mempunyai prosedur penyelesaian masalah, mampu membuat analisis dan diwajibkan untuk membuat evaluasi terhadap hasil penyelesaiannya (Purba dan Sirait, 2017). Berdasarkan penjelasan tersebut, dapat diketahui bahwa dampak dari pembelajaran ini adalah peserta didik bisa memiliki kemampuan penyelesaian masalahnya sendiri. Hal ini sejalan dengan pendapat yang mengatakan bahwa LAPS-Heuristic adalah model pembelajaran yang menuntun peserta didik dalam menyelesaikan masalah (Ngalimun, 2016).

Disamping ada model pembelajaran yang menentukan keberhasilan proses belajar mengajar, ada hal-hal lain juga yang bisa membantu mempermudah pembelajaran. Kemajuan teknologi yang menawarkan kemudahan bagi manusia untuk mendapatkan informasi dalam waktu singkat. Dengan adanya internet kebutuhan manusia semakin mudah untuk terpenuhi. Dalam dunia pendidikan internet juga bisa bermanfaat sebagai media pembelajaran. Terdapat tiga manfaat internet sebagai sebagai media untuk pembelajaran, yaitu sebagai komplemen (pelengkap), suplemen (tambahan) dan subtitusi (pengganti). Internet menjadi media pembelajaran menjadi salah satu opsi yang mendukung kegiatan pembelajaran (Munir, 2009). Pemanfaatan internet sebagai media pembelajaran memungkinkan terjadi jika tersedia sarana pembelajaran online (Munadi, 2010). Pembelajaran online diartikan sebagai jenis pembelajaran yang memungkinkan tersampainya bahan ajar kepada siswa dengan menggunakan media internet atau yang sejenisnya. Penggunaan WhatsApp Messenger meningkat tajam di dunia nasional maupun internasional. WhatsApp adalah aplikasi Messenger seperti SMS dengan berbantuan data internet dan berfitur pendukung yang sangat menarik. Aplikasi tersebut juga sangat berpotensi untuk dimanfaatkan sebagai salah satu alat pembelajaran. Penggunaan WhatsApp di era digital ini sangat memungkinkan untuk di gunakan dalam pembelajaran baik dalam wilayah sekolah atau Perguruan Tinggi. Survei menunjukkan bahwa $90 \%$ pelajar, mahasiswa maupun tenaga pengajar telah menggunakan WhatsApp dalam kehidupan sehari-hari baik untuk urusan pribadi maupun pembelajaran. Diantara fitur yang dimiliki WhatsApp adalah Gallery yang berfungsi untuk menambahkan foto, Contact untuk berbagi kontak, Camera untuk mengambil gambar, Audio untuk mengirim suara, Maps untuk 
menyebarkan koordinat suatu peta dan yang tidak kalah penting adalah Document untuk menambah dan berbagi dokumen apapun. Semua fitur tersebut dapat digunakan dengan sangat cepat dan mudah melalui WhatsApp. Oleh karena itu, dalam proses pembelajaran, penggunaan WhatsApp dibutuhkan untuk mendorong siswa dalammencari pengetahuan yang luas. Group WhatsApp Messenger adalah salah satu layanan diskusi yang bisa menampung hingga 256 peserta, jumlah yang snagat banyak dan bisa sangat mudah dikumpulkan dalam satu aplikasi. Di dalamnya, para peserta bisa berdiskusi dan bertukar apapun melalui fitur yang sudah dijelaskan di atas tadi.

Berdasarkan latar belakang yang sudah diuraika di atas, maka tujuan dari penelitian ini adalah untuk; (1) melihat peningkatan hasil belajar peserta didik dalam menyelesaiakn soal cerita barisan dan deret melalui pembelajaran LAPS Heuristik berbantuan WhatsApp; melihat peningkatan disposisi matematis peserta didik dalam menyelesaikan soal cerita barisan dan deret melalui pembelajaran LAPS Heuristik berbantuan aplikasi WhatsApp.

\section{METODE}

Metode yang digunakan dalam penelitian ini adalah eksperimental dengan desain pretes-postes dan kelompok kontrol yang dipilih acak (Pretst-posttest control Group Design). Dengan desain ini, subyek mula-mula diberikan pretes dan angket, lalu diberi pembelajaran LAPS Heuristik dan kemudian diberikan postes dan angket untuk mengetahui peningkatan hasil belajar dan disposisi matematis peserta didik pada materi barisan dan deret. Hasil prees dan postes dianalisis untuk memperoleh nilai gain ternormalisasi sebagai peningkatan hasil belajar dan disposisi matematis. Metode ini dipilih sesuai dengan tujuan penelitian yang ingin melihat penigkatan dari hasil belajar dan dispoosisi matematis peserta didik dari pembelajaran LAPS Heuristik. Penelitian dilakukan di salah satu Madrasah Aliyah di Kabupaten Gresik Pada tahun 2019/2020. Alasan menggunakan sekolah ini adalah karena Madrasah Aliyah ini salah bsatu sekolah level sedang. Karena jika memilih sekolah level atas, dikhawatirkan banti hasilnya baik, bukan karena pembelajaran. Dan tidak dipilihnya sekolah level bawah, juga karena ditakutkan nanti hasilnya cenderung rendah bukan karena hasil pembelajaran (Darhim, 2004:64). Sampel dalam penelitian ini dipilih dua kelas, yaitu XI 
IPA dan XI IPS dengan kemampuan awal sama. Digunakannya kelas ini karena memang dirasa cocok kelas tersebut dengan penelitian yang hendak dilakukan.

Penelitian dilakukan sebanyak tiga hari berturut-turut. Untuk pretes dan postes masing-masing satu hari dan sisanya untuk pembelajaran.

Metode yang digunakan dalam penelitian meliputi tes dan angket. Sedangkan instrumen yang digunakan yaitu instrumen tes, instrumen angket yang sudah divalidasi oleh ahli.

Analisis data yang dilakukan pertama adalah kemampuan disposisi matematis dalam menyelesaikan soal cerita. Kemampuan awal disposisi digunakan untuk mengetahui kedua kelas apakah berasal dari keadaan yang sama atau tidak. Data kemampuan awal diperoleh dari hasil pretes dan angket. Setelah sebelumnya dilakukan uji n+ormalitas dan homogenitas, diperoleh bahwa keduanya berdistribusi normal dan homogen sehingga untuk pengujian hipotesis dilakukan uji t. Hasil uji menunjukkan tidak terdapat perbedaan rata-rata yang signifikan di kedua kelas, ini berarti kedua kelas mempunyai kemampuan awal yang sama.

Selanjutnya dilakukan proses pembelajaran di kedua kelas, dengan satu kelas menggunakan pembelajaran LAPS Heuristik dan satu lagi menggunakan pembelajran konvensional.

\section{HASIL DAN PEMBAHASAN}

Dari data yang telah dianalisis diketahui bahwa taraf signifikan (2tailed) pretest hasil belajar peserta didik adalah $0.769>0.05$ maka $H_{0}$ diterima, berarti tidak ada perbedaan rata-rata kemampuan awal pemecahan masalah siswa antara kelas LAPS-Heuristik sama dengan kelas konvensional sebelum diberi perlakuan. Hal tersebut terbukti dari rata-rata kelas LAPS-Heuristik adalah 40.36 dan rata-rata kelas konvensional adalah 39.33. Sehingga dapat disimpulkan hasil belajar kelas LAPS-Heuristik dan kelas konvensional adalah sama. Lebih jelasnya, perbandingn pretes pada kelas kontrol dan eksperimen dapat dilihat pada Tabel 1 berikut.

Tabel 1. Deskripsi hasil pretes kelas kontrol dan eksperimen

\begin{tabular}{lll}
\hline \multirow{2}{*}{ Statistika } & \multicolumn{2}{c}{ Kelas } \\
& Eksperimen & Kontrol \\
\hline Jumlah & 22 & 21 \\
Siswa & & \\
Maksimum & 61 & 55 \\
Minimum & 22 & 21 \\
Mean & 40.36 & 39.33 \\
Median & 38.00 & 41.00 \\
Modus & 38.00 & 31.30 \\
Varians & 142.81 & 118.23 \\
Simpangan & 11.95 & 10.88 \\
Baku & & \\
\hline
\end{tabular}


Namun setelah diberi perlakuan kemudian diberikan posttest, diketahui bahwa taraf signifikan (2-tailed) hasil belajar peserta didik adalah $0.000<$ 0.05 maka $H_{0}$ ditolak dan $H_{1}$ diterima yang berarti rata-rata hasil belajar kelas LAPS-Heuristik lebih baik daripada hasil belajar peserta didik kelas konvensional. Hal tersebut terbukti bahwa rata-rata posttest kelas LAPS-Heuristik adalah 83.68 dan rata-rata kelas konvensional adalah 72.33. Hal tersebut juga didukung oleh penelitian Primandari (2010), berdasarkan hasil penelitiannya, pada pelaksanaan siklus pertama diperoleh presentase kemampuan memahami masalah sebesar 89,06\%, kemampuan merencanakan pemecahan masalah sebesar 77,78\%, kemampuan menyelesaikan masalah sebesar 63,26\%, dan kemampuan menafsirkan solusi sebesar 56,94\%. Hasil tersebut menunjukkan bahwa kemampuan pemecahan masalah siswa sudah baik pada keempat aspek. Sedangkan pada pelaksanaan siklus kedua diperoleh presentase sebagai berikut: kemampuan memahami masalah sebesar 95,99\%, kemampuan merencanakan pemecahan masalah sebesar 78,57\%, kemampuan menyelesaikan masalah sebesar 82,29\%, dan kemampuan menafsirkan solusi sebesar $80,56 \%$. Semua presentase aspek pemecahan masalah pada siklus kedua sudah mencapai kriteria tinggi. Nilai ratarata yang dihasilkan siswa pada siklus kedua meningkat jika dibandingkan hasil tes sebelumnya. Nilai rata-rata yang diperoleh siswa ketika tes pada akhir siklus pertama adalah $71,99 \%$, sedangkan nilai rata-rata siswa ketika tes akhir siklus kedua adalah $84,46 \%$ atau meningkat sebanyak $17,32 \%$. Hal ini menunjukkan adanya peningkatan kemampuan siswa dalam memecahkan masalah. Siswaa mempunyai nilai KKM hanya 1 orang, sehingga siswa yang tuntas belajar mencapai 93,93\%.

Sedangkan berdasarkan penelitian Wahyuni (2015) dengan subjek penelitian sebanyak 5 orang peserta didik yang memperoleh peringkat pertama, kuartil pertama, kuartil kedua, kuartil ketiga, dan terakhir pada tes pendahuluan kemampuan pemecahan masalah. Analisis kualitatif menunjukkan terjadi peningkatan perilaku pada indikator kedisiplinan dan kemampuan pemecahan masalah. Indeks Gain rataan karakter kedisiplinan pertemuan pertama hingga kelima diperoleh, kelima subjek peneliti dari subjek peringkat pertama hingga peringkat akhir berturut-turut adalah 0,$92 ; 0,95 ; 0,89 ; 0,78$; dan 0,81 termasuk kategori tinggi. Peningkatan kemampuan pemecahan masalah juga termasuk 
kategori tinggi dengan indeks Gain 0,94; 0,$85 ; 0,80 ; 0,87 ;$ dan $0 ; 87$. Nilai tes kemampuan pemecahan masalah kelima subjek penelitian adalah 100;100; 94,3; 88,6; dan 84,2. Berdasarkan hasil penelitian, dapat disimpulkan bahwa karakter kedisiplinan dan kemampuan pemecahan masalah peserta didik mencapai KKM melalui penerapan model pembelajaran LAPS-Heuristik.

Sehingga dari penelitian tersebut menunjukkan bahwa pencapaian peningkatan hasil belajar peserta didik dalam menyelesaikan masalah yang memperoleh pembelajaran kooperatif LAPS-Heuristik lebih baik dibandingkan pencapaian peningkatan hasil belajar pesrta didik dalam menyelesaikan masalah yang memperoleh model pembelajaran lain. Hasil perbandingan kelas kontrol dan eksperimen saat postes bisa dilihat lebih detail pada Tabel 2 .

Tabel 2. Deskripsi Hasil Postes Kelas

Kontrol dan Eksperimen

\begin{tabular}{lll}
\hline Statistika & $\begin{array}{l}\text { Kelas } \\
\text { Eksperimen }\end{array}$ & Kontrol \\
\hline Jumlah & 22 & 21 \\
Siswa & & \\
Maksimum & 94 & 84 \\
Minimum & 70 & 60 \\
Mean & 83.68 & 72.33 \\
Median & 85.00 & 74.00 \\
Modus & 85.00 & 65.5 \\
Varians & 51.09 & 59.23 \\
Simpangan & 7.15 & 7.70 \\
Baku & & \\
\hline
\end{tabular}

Berdasarkan hasil analisis N-Gain yang terdapat pada Tabel 4.23 diketahu bahwa taraf signifikan (2-tailed) hasil belajar adalah $0.000>0.05$ maka $\mathrm{H}_{0}$ ditolak dan $\mathrm{H}_{1}$ diterima yang berarti ratarata N-Gain kemampuan akhir hasil belajar siswa kelas LAPS-Heuristik lebih baik daripada $\mathrm{N}$-Gain kemampuan hasil belajar peserta didik kelas konvensional. Hal tersebut terbukti bawa N-Gain kemampuan hasil belajar peserta didik kelas LAPS-Heuristik adalah 0.74 yang tergolong kriteria $\mathrm{N}$-Gain tingkat baik dan N-Gain kemampuan hasil belajar peserta didik kelas konvensional adalah 0.55 yang tergolong tingkat sedang.

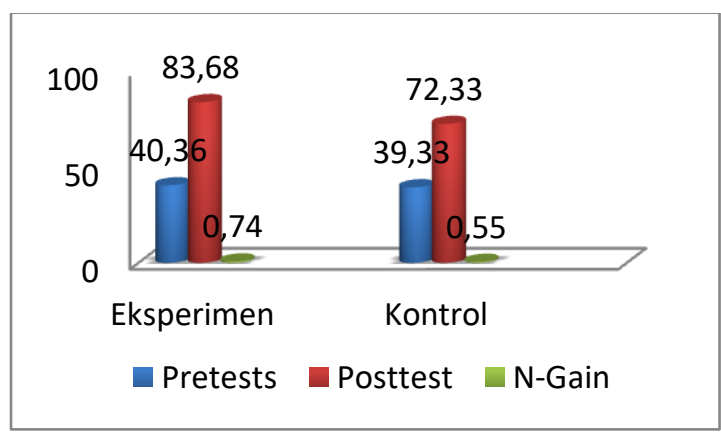

Gambar 1. Perbedaan Rata-Rata Hasil Belajar Peserta Didik Kelas Eksperimen dan Kelas Kontrol

Hasil analisis angket pretest disposisi matematis kelas LAPS-Heuristik dan kelas konvensional diketahui bahwa taraf signifikan (2-tailed) adalah $0.571>$ 0.05 maka $H_{0}$ diterima berarti tidak ada perbedaan rata-rata kemampuan awal disposisi matematis antara siswa kelas 
LAPS-Heuristik dengan siswa kelas konvensional sebelum diberi perlakuan. Hal tersebut terbukti bahwa rata-rata pretest kelas LAPS-Heuristik adalah 40.36 dan rata-rata kelas konvensional adalah 39.33. Sehingga dapat disimpulkan kemampuan disposisi matematis siswa kelas LAPS-Heuristik dan kelas konvensional adalah sama. Lebih jelasnya bisa dilihat pada Tabel 3.

Tabel 3. Deskripsi Pretes Angket Kelas Kontrol Dan Eksperimen

\begin{tabular}{lll}
\hline Statistika & $\begin{array}{l}\text { Kelas } \\
\text { Eksperimen }\end{array}$ & Kontrol \\
\hline Jumlah & 22 & 21 \\
Siswa & & \\
Maksimum & 75 & 74 \\
Minimum & 56 & 55 \\
Mean & 40.36 & 39.33 \\
Median & 61.00 & 66.00 \\
Modus & 61.80 & 59.50 \\
Varians & 39.20 & 34.29 \\
Simpangan & 6.27 & 5.86 \\
Baku & & \\
\hline
\end{tabular}

Namun setelah diberi perlakuan dan kemudian diberi posttest, diketahui bahwa taraf signifikan (2-tailed) disposisi matematis siswa adalah $0.000<0.05$ maka $H_{0}$ ditolah dan $H_{1}$ diterima yang berarti terdapat perbedaan rata-rata disposisi matematis antara siswa kelas LAPS-Heuristik dan siswa kelas konvensional. Hal tersebut terbukti bahwa rata-rata disposisi matematis siswa kelas LAPS-Heuristik adalah 83.68 dan rata-rata kelas konvensional adalah 72.33 yang terdapat pada Tabel 4.

Tabel 4. Deskripsi Postes Angket Kelas Eksperimen Dan Kontrol

\begin{tabular}{lll}
\hline Statistika & $\begin{array}{l}\text { Kelas } \\
\text { Eksperimen }\end{array}$ & Kontrol \\
\hline Jumlah & 22 & 21 \\
Siswa & & \\
Maksimum & 96 & 90 \\
Minimum & 83 & 80 \\
Mean & 89.73 & 84.67 \\
Median & 90.00 & 85.00 \\
Modus & 86.00 & 80.00 \\
Varians & 15.16 & 12.03 \\
Simpangan & 3.90 & 3.47 \\
Baku & & \\
\hline
\end{tabular}

Hasil tersebut menunjukkan bahwa pencapaian peningkatan kemampuan disposisi matematis siswa yang memperoleh pembelajaran kooperatif LAPS-Heuristik lebih baik dibandingkan pencapaian peningkatan kemampuan disposisi matematis siswa yang memperoleh model pembelajaran lain.

Dari hasil analisis N-gain yang terdapat pada Tabel Tabel 4.32 diketahui bahwa taraf signifikan (2-tailed) disposisi matematis siswa adalah $0.000>0.05$ maka $\mathrm{H}_{0}$ ditolak dan $\mathrm{H}_{1}$ diterima yang berarti rata-rata N-Gain disposisi matematis siswa kelas LAPSHeuristik lebih baik daripada N-Gain disposisi matematis siswa kelas konvensional. Hal tersebut terbukti bahwa N-Gain disposisi matematis kelas LAPS-Heuristik adalah 0.73 yang 
tergolong kriteria N-Gain tingkat tinggi dan N-Gain kelas konvensional adalah 0.57 yang tergolong $\mathrm{N}$-Gain tingkat sedang.

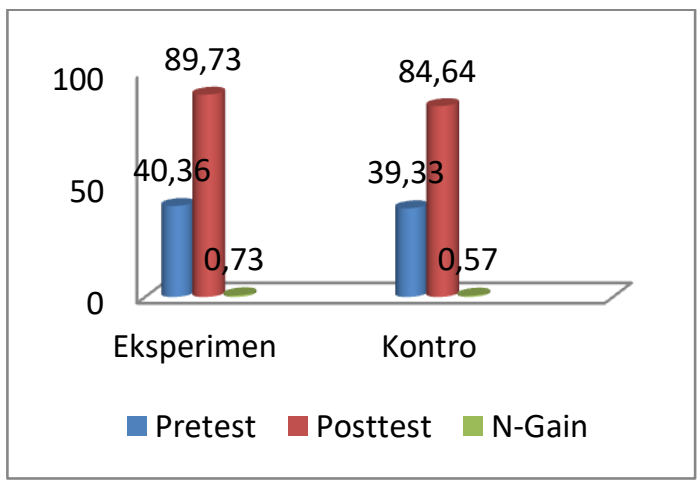

Gambar 2. Perbedaan Rata-Rata Hasil

Belajar Peserta Didik Kelas Eksperimen dan Kelas Kontrol

Peningkatan disposisi matematis juga didukung degan penelitian dari Nurbaiti Widyasari (2016), dari penelitian ini menunjukkan hasil secara kualitatif diketahui siswa kelas VIII dapat memetaforakan suatu konsep matematika serta dapat menghubungkan antara satu konsep dengan konsep yang lain. Selanjutnya hasil secara kuantitatif menunjukkan bahwa peningkatan kemampuan disposisi matematis peserta didik dengan kelas pembelajaran metaphorical thinking tidak ada perbedaan dengan kelas pembelajaran konvensional, serta tidak terdapat pengaruh hubungan antara pendekatan pembelajaran dengan kemampuan awal matematis terhadap kemampuan disposisi matematis peserta didik.

\section{KESIMPULAN DAN SARAN}

Berdasarkan hasil penelitian dan pembahasan yang telah diuraikan di atas, dapat ditarik kesimpulan bahwa ada peningkatan hasil belajar dan disposisi matematis peseerta didik dalam menyelesaikan soal cerita barisan dan deret berbantuan WhatsApp baik di kels kontrol maupuin eksperimen; dan peningkatan hasil belajar dan disposisi matematis di kelas eksperimen yang menggunakan pembelajaran LAPS Heuristik itu lebih baik secara keseluruhan dibanding kelas yang menggunakan pembelajaran konvensional.

Berdasarkan simpulan di atas, dalam pembelajaran matematika kemampuan awal peserta didik perlu dilihat sebagai acuan dalam penelitian. Peneliti juga merkomendasikan kepada guru dalam menggunakan pembelajaran LAPS Heuristik guna meningkatkan disposisi matematis maupun hasil belajar dalam menyelesaikan soal cerita. Perlu dilakukan penelitian yang lain mengenai pembelajaran LAPS Heuristik apabila diterapkan pada materi lain di jenjang sekolah yang lain juga.

\section{DAFTAR PUSTAKA}

Adiarta, I Gusti Made, dkk. (2014). "Pengaruh Model Pembelajaran 
LAPS-Heuristic Terhadap Hasil

Belajar Tik Ditinjau Dari

Kreativitas Siswa Kelas VIII SMP

Negeri 1 Payangan”. Jurnal

Penelitian dan Evaluasi

Pendidikan. Vol. 4(4). .

Bsnp. (2006). Standar kompetensi dan

kompetensi dasar smp/mts. Jakarta:

Balitbang.

Dahlan, J. A. (2011). Analisis Kurikulum

Matematika. Jakarta: universitas terbuka.

Fitria, N. F. N., Hidayani, N., Hendriana, H., \& Amelia, R. (2018). Analisis Kemampuan Pemecahan Masalah Matematik Siswa SMP dengan Materi Segitiga dan Segiempat. Edumatica: Jurnal Pendidikan Matematika, Vol. 8(1), pp. 49-57.

Hendriana, H \& Soemarmo, U. (2014).

Penilaian Pembelajaran

Matematika. Bandung: PT Refika Aditama.

Hasanah, M \& Surya, E. (2017).

Differences in the Abilities of Creative Thinking and Problem Solving of Students in Mathematics by Using Cooperative Learning and Learning of Problem Solving. International Journal of Sciences: Basic and Applied Research (IJSBAR). Vol. 34(1), pp. 286-299.
Mullis, I.V.S., Martin, M.O., Foy P., Arora, A. (2012). TIMSS 2011 International Result in Mathematics. Netherlands: IEA.

Munadi, Y. (2010). Media Pembelajaran. Jakarta: Gaung Persada (GP) Press. Munir, (2009). Pembelajaran Jarak Jauh Berbasis Teknologi Informasi dan Komunikasi. Bandung: CV Alfabeta.

Ngalimun. (2016). Strategi dan Model Pembelajaran. Yogyakarta: Aswaja Pressindo.

Priyo, Dwi. (2011). Masalah-masalah Dalam Pembelajaran Matematika. Malang: Widya Warta.

Purba, O. N., \& Sirait, S. (2017). Peningkatan Kemampuan Pemecahan Masalah dengan Model LAPS-Heuristic di SMA Shafiyyatul Amaliyah. Jurnal Mathematic Paedagogic, Vol. 2(1), pp. 31-39.

Putri W, Mella. 2008. Analisis Kesulitan Menyelesaikan Soal Cerita Pada Pelajaran Matematika Kelas VII Semester Ganjil SMP Tri Sukses Natar Tahun Ajaran 2008/2009. Skripsi. Lampung: Unila.

Rahman, I. S., Murnaka, N. P., \& Wiyanti, W. (2018). Pengaruh Model Pembelajaran Laps (Logan Avenue Problem Solving)-Heuristik 
Terhadap Kemampuan Pemecahan

Masalah. Wacana akademika:

Majalah Ilmiah Kependidikan, Vol.

2(1), pp. 48-60.

Shodikin, A. (2015). Interaksi

Kemampuan Awal Matematis

Siswa dan Pembelajaran Dengan

Strategi Abduktif-Deduktif

Terhadap Peningkatan Kemampuan

Penalaran dan Disposisi Matematis

Siswa. INSPIRAMATIKA, Vol.

1(1), pp. 61-72.

Sumarmo, U. (2012). Pendidikan

Karakter Serta Pengembangan

Berpikir dan Disposisi Matematik

Dalam Pembelajaran Matematika.

Seminar Pendidikan Matematika,

25 Februari 2012.

Wijaya, Ariyadi. 2012. Pendidikan

Matematika Realistik. Yogyakarta:

Graha Ilmu. 